\title{
A STUDY OF CLINICAL PROFILE OF MALARIA AND ITS ACUTE COMPLICATIONS CAUSED BY DIFFERENT SPECIES OF PLASMODIUM IN CHILDREN
}

\author{
A. Vidyullatha1, V. C. Srinivas Reddy², Ch. Lakshmi Madhulika ${ }^{3}$ \\ ${ }_{1}^{1}$ Associate Professor, (Designated), Department of Paediatrics, Andhra Medical College, Visakhapatnam, Andhra Pradesh, India. \\ ${ }^{2}$ Associate Professor, (Designated), Department of General Medicine, Andhra Medical College, Visakhapatnam, Andhra Pradesh, India. \\ ${ }^{3}$ DNB Resident, Government District General Hospital, Department of Paediatrics, Vizianagaram, Andhra Pradesh, India.
}

\section{ABSTRACT}

\section{BACKGROUND}

Malaria is an insect-borne parasitic infection of tremendous global importance. India alone contributes 80\% of south East Asia's malaria burden. Children are at the highest risk for severe disease and death between six months and five years of age.

\section{MATERIALS AND METHODS}

The aim of the study is to assess the clinical profile and complications caused by different species of plasmodium in children with malaria. This is a prospective, cross-sectional, observational study. Children from 1 month to 15 years of age diagnosed with malaria by standard laboratory tests are enrolled.

\section{RESULTS}

Majority of the study subjects belong to age group of $<5$ years (50.9\%). $64 \%$ of the study subjects are boys and $36 \%$ are girls (36\%). All the study subjects presented with fever (100\%). Majority of the study subjects presented with splenomegaly (74.6\%). The most common complication was anaemia (35.08\%) followed by hepatitis $(11.40 \%)$. Out of 40 anaemic patients, majority $(62.5 \%)$ belong to $<5$ years age group. In smear for MP, PF is positive in $75.4 \%$.

\section{CONCLUSION}

Cerebral Malaria, renal failure, bleeding diathesis, metabolic acidosis, pulmonary oedema, repeated convulsions, shock were noted only in Falciparum malaria. Mortality was $1.8 \%$ in this study. Majority of patients recovered.

\section{KEY WORDS}

Malaria, Species of Plasmodium, Acute Complications, Children HOW TO CITE THIS ARTICLE: Vidyullatha A, Reddy VCS, Madhulika CL. A study of clinical profile of malaria and its acute complications caused by different species of plasmodium in children. J. Evolution Med. Dent. Sci. 2019;8(09):604-609, DOI: $10.14260 /$ jemds/2019/134

\section{BACKGROUND}

Malaria is an insect-borne parasitic infection of tremendous global importance. According to the WHO, there were 214 million cases and 438, 000 deaths attributed to malaria in 2015․ A declining trend has been observed in the global incidence of malaria in recent years; in paediatric malaria also, the incidence decreased from $33 \%$ in 2000 to $16 \%$ in $2015 .{ }^{1}$ India alone contributes $80 \%$ of south East Asia malaria burden. ${ }^{2}$ India has by far the greatest estimated Plasmodium vivax burden of any country. Around $30 \%$ of all P. vivax cases in India occur in children aged 1-14 years, though these represent just $12 \%$ of the total population. ${ }^{3}$ In a recent study by "million death collaboration", it was estimated that malaria accounts for 205, 000 deaths per year in India, with 55, 000 deaths occurring in early childhood. ${ }^{3}$ Among the different human species of these protozoa, Plasmodium falciparum is responsible for most fatalities. ${ }^{1}$

'Financial or Other Competing Interest': None.

Submission 07-01-2019, Peer Review 15-02-2019,

Acceptance 22-02-2019, Published 04-03-2019.

Corresponding Author:

Dr. V. C. Srinivas Reddy

Associate Professor, (Designated),

Department of General Medicine,

Andhra Medical College, Visakhapatnam,

Andhra Pradesh, India.

E-mail: drvcsr@yahoo.co.in

DOI: $10.14260 /$ jemds $/ 2019 / 134$
Young children manifest this disease in many different ways, but the classic picture of malaria, with periodic fever, shivering, and sweating, is not observed. Children are at highest risk for severe disease and death between six months and five years of age: during this period children are most vulnerable as they have lost maternal immunity and they haven't yet developed specific immunity to infection.

Haematological and biochemical parameters are often abnormal: Features of severe or complicated malaria include respiratory distress, acidosis $(\mathrm{pH}<7.3)$, hypoglycaemia $(<2.2$ $\mathrm{mmol} / \mathrm{l})$, elevated aminotransferases, severe anaemia $(\mathrm{Hb}<5$ $\mathrm{g} / \mathrm{dl}$ ), and high parasitaemia (defined as $>5 \%-10 \%$ infected erythrocytes or more than 500000 infected erythrocytes per microliter) ${ }^{4}$. Considering the above facts, the present study was undertaken to find out the spectrum of clinical manifestations, infecting species, age distribution and complications in children admitted with malaria.

\section{Aim of The Study}

To assess the clinical profile and complications caused by different species of plasmodium in children with malaria.

\section{MATERIALS AND METHODS}

This is a descriptive study conducted at Government District General Hospital, Vizianagaram, Andhra Pradesh, in the Department of paediatrics for a period of one year from June 2017 to May 2018. Children from ages of 1 month to 15 years of age diagnosed with malaria by standard laboratory tests are enrolled until sample size is attained after taking due 
consent. The study protocol is approved by Ethical committee.

\section{Inclusion Criteria}

1. Children from 1 month to $\mathbf{1 5}$ years of age admitted in paediatric ward diagnosed with malaria.

2. Diagnosis of malaria was done by using Smear for malarial parasite and/or RDT.

\section{Exclusion Criteria}

1. Children on empirical treatment for malaria but later found negative.

2. Children not willing to participate.

3. Children with other infections like enteric fever, meningitis, TB etc with coincidental smear positivity for malaria.

\section{Statistical Analysis}

Data entry and statistical analysis was performed with the help of Microsoft excel 2007 and SPSS version 20.0, while categorical variables are presented as number and percentages. Chi-square test is used to compare differences in categorical variables. The statistical significance level is fixed at $\mathrm{p}<0.05$.

RESULTS

\begin{tabular}{||c|c|c|}
\hline Age Category & Frequency & Percent \\
\hline < YEARS & 58 & 50.9 \\
\hline 5-10 YEARS & 41 & 36.0 \\
\hline 11-15 YEARS & 15 & 13.2 \\
\hline Total & 114 & 100.0 \\
\hline \multicolumn{2}{|c|}{ Mean $\pm \mathrm{SD}=5.9704 \pm 3.77861$} \\
\hline \multicolumn{2}{|c|}{ Table 1. Age Distribution } \\
\hline
\end{tabular}

Majority of the study subjects belong to age group of $<5$ years $(50.9 \%)$, followed by age group of $5-10$ years (36\%) and $11-15$ years $(13.2 \%)$.

\begin{tabular}{|c|c|c|}
\hline Gender & Frequency & Percent \\
\hline Girls & 41 & $36 \%$ \\
\hline Boys & 73 & $64 \%$ \\
\hline Total & 114 & $100 \%$ \\
\hline \multicolumn{2}{|c|}{ Table 2. Gender Distribution } \\
\hline
\end{tabular}

$64 \%$ of the study subjects are boys and $36 \%$ by girls (36\%).

\begin{tabular}{|c|c|c|}
\hline Locality & Frequency & Percent \\
\hline Rural & 28 & $24.6 \%$ \\
\hline Tribal & 83 & $72.8 \%$ \\
\hline Urban & 3 & $2.6 \%$ \\
\hline Total & 114 & $100 \%$ \\
\hline
\end{tabular}

Table 3. Distribution of Children Based on Their Locality
Majority of the study subjects belong to tribal locality (72.8\%), followed by rural (24.6\%) and urban (2.6\%).

\begin{tabular}{|l|c|c||}
\hline \multicolumn{1}{|c|}{ Symptoms } & Frequency & Percent \\
\hline Fever & 114 & $100 \%$ \\
\hline Headache & 51 & $44.7 \%$ \\
\hline Myalgia & 34 & $29.8 \%$ \\
\hline Vomiting & 54 & $47.4 \%$ \\
\hline Loose stools & 26 & $22.8 \%$ \\
\hline Abdominal distension & 44 & $38.6 \%$ \\
\hline Jaundice & 9 & $7.9 \%$ \\
\hline Bleeding & 8 & $7.0 \%$ \\
\hline Pallor & 21 & $18.4 \%$ \\
\hline Altered Sensorium & 24 & $21.1 \%$ \\
\hline Convulsions & 7 & $6.1 \%$ \\
\hline Dark urine & 5 & $4.4 \%$ \\
\hline Shortness of Breath & 2 & $1.8 \%$ \\
\hline \multicolumn{2}{|c|}{ Table 4. Clinical Presentation of Malaria } \\
\hline
\end{tabular}

All the study subjects presented with fever (100\%). $47.4 \%$ presented with vomiting, $44.7 \%$ with headache, $38.6 \%$ study subjects presented with abdominal distension, $29.8 \%$ with myalgia, $22.8 \%$ presented with loose stools, $21.1 \%$ presented with altered sensorium, $18.4 \%$ presented with pallor, Jaundice observed in $7.9 \%$, bleeding in $7.0 \%$, convulsions in $6.1 \%$, dark urine in $4.4 \%$ and shortness of breath in $1.8 \%$ of the study subjects.

\begin{tabular}{|l|c|c|}
\hline \multicolumn{1}{|c|}{ Signs } & Frequency & Percent \\
\hline Pallor & 52 & $45.6 \%$ \\
\hline Icterus & 12 & $10.5 \%$ \\
\hline Hepatosplenomegaly & 12 & $10.5 \%$ \\
\hline Splenomegaly & 85 & $74.6 \%$ \\
\hline \multicolumn{2}{|c|}{ Table 5. Clinical Signs of Malaria } \\
\hline
\end{tabular}

Majority of the study subjects presented with splenomegaly $(74.6 \%)$, followed by pallor (45.6\%), icterus $(10.5 \%)$ and hepatosplenomegaly $(10.5 \%)$.

\begin{tabular}{|l|c|c|}
\hline Complications & Frequency & Percent \\
\hline Anemia & 40 & $35.08 \%$ \\
\hline Hypoglycemia & 4 & $3.50 \%$ \\
\hline Cerebral Malaria & 6 & $5.26 \%$ \\
\hline Hepatitis & 13 & $11.40 \%$ \\
\hline Renal failure & 4 & $3.50 \%$ \\
\hline Bleeding diathesis & 6 & $5.36 \%$ \\
\hline Metabolic acidosis & 4 & $3.50 \%$ \\
\hline Pulmonary edema & 2 & $1.75 \%$ \\
\hline Repeated convulsions & 1 & $0.87 \%$ \\
\hline Shock Table 6. Complications of Malaria \\
\hline \multicolumn{2}{|c|}{1} \\
\hline
\end{tabular}


In our study, the most common complication was anaemia (35.08\%) followed by hepatitis (11.40\%), Bleeding diathesis (5.36\%), cerebral malaria (5.26\%), hypoglycaemia (3.50\%), renal failure $(3.50 \%)$, metabolic acidosis $(3.50 \%)$, pulmonary oedema $(1.75 \%)$, repeated convulsions $(0.87 \%)$ and shock $(0.87 \%)$.

\begin{tabular}{|c|c|c|c|c|c|c|c|c|}
\hline \multirow[t]{2}{*}{ Complications } & \multicolumn{2}{|c|}{$<5$ Yrs } & \multicolumn{2}{|c|}{ 5-10 Yrs } & \multicolumn{2}{|c|}{ 11-15 Yrs } & \multirow[t]{2}{*}{ Total } & \multirow[t]{2}{*}{ P value } \\
\hline & $\mathrm{n}$ & $\%$ & $\mathrm{n}$ & $\%$ & $\mathrm{n}$ & $\%$ & & \\
\hline Anemia & 25 & 62.5 & 12 & 30 & 3 & 7.5 & 40 & 0.15 \\
\hline Hypoglycemia & 3 & 75 & 1 & 25 & 0 & 0 & 4 & 0.56 \\
\hline Cerebral Malaria & 6 & 100 & 0 & 0 & 0 & 0 & 6 & $0.04^{*}$ \\
\hline Hepatitis & 2 & 15.4 & 7 & 53.8 & 4 & 30.8 & 13 & $0.01^{*}$ \\
\hline Renal failure & 2 & 50 & 1 & 25 & 1 & 25 & 4 & 0.74 \\
\hline Bleeding diathesis & 2 & 33.3 & 3 & 50 & 1 & 16.7 & 6 & 0.67 \\
\hline Metabolic acidosis & 3 & 75 & 1 & 25 & 0 & 0 & 4 & 0.56 \\
\hline Pulmonary edema & 2 & 100 & 0 & 0 & 0 & 0 & 2 & 0.37 \\
\hline Repeated convulsions & 0 & 0 & 1 & 100 & 0 & 0 & 1 & 0.40 \\
\hline Shock & 1 & 100 & 0 & 0 & 0 & 0 & 1 & 0.61 \\
\hline
\end{tabular}

\section{Table 7. Complications of Malaria According to Age Groups}

Out of 40 anaemic patients, majority (62.5\%) belongs to $<5$ years. Out of 4 hypoglycaemic patients, majority $(75 \%)$ belongs to $<5$ years. Out of 6 cerebral malaria patients, all belongs to $<5$ years. Out of 13 hepatitis patients, majority (53.8\%) belongs to 5-10 years. Out of 4 patients with renal failure, majority (50\%) belongs to $<5$ years. Out of 6 patients with bleeding diathesis, majority $(50 \%)$ belongs to $5-10$ years. Out of 4 patients with metabolic acidosis, majority $(75 \%)$ belongs to $<5$ years. One patient had repeated convulsions in the age group of 5-10 years. One patient had shock in the age group of $<5$ years. Statistical significance was found in cerebral malaria and hepatitis.

\begin{tabular}{|c|c|c|c|c||}
\hline \multirow{2}{*}{ Laboratory tests } & \multicolumn{2}{|c|}{ Smear for MP } & \multicolumn{2}{c|}{ RDT } \\
\cline { 2 - 5 } & Frequency & Percent & Frequency & Percent \\
\hline PF & 86 & 75.4 & 82 & 71.9 \\
\hline PF+PV & 8 & 7.0 & 13 & 11.4 \\
\hline PV & 20 & 17.5 & 19 & 16.7 \\
\hline Total & 114 & 100 & 114 & 100 \\
\hline \multicolumn{4}{|c|}{ Table 8. Laboratory Tests for Diagnosis } \\
\hline \multicolumn{4}{|c|}{ RDT- Rapid Diagnostic Test, MP- Malarial Parasite } \\
\hline
\end{tabular}

In smear for $\mathrm{MP}, \mathrm{PF}$ is positive in $75.4 \%, \mathrm{PF}+\mathrm{PV}$ in $7 \%$ and $\mathrm{PV}$ in $17.5 \%$ cases. In RDT, PF is positive in $71.9 \%, \mathrm{PF}+\mathrm{PV}$ in $11.4 \%$ and $P V$ in $16.7 \%$ cases.

\begin{tabular}{||c|c|c|c|c|c|c|c|c|}
\hline \multicolumn{1}{|c|}{$\begin{array}{c}\text { Laboratory } \\
\text { Investigations }\end{array}$} & \multicolumn{2}{|c|}{ PF } & \multicolumn{2}{|c|}{ PF+PV } & \multicolumn{2}{|c|}{ PV } & \multicolumn{1}{c|}{ Total } & \multicolumn{1}{c|}{ P } \\
\cline { 2 - 8 } & $\mathbf{n}$ & $\%$ & $\mathbf{n}$ & $\%$ & $\mathbf{n}$ & $\%$ & & Value \\
\hline Increased TSB & 9 & 69.2 & 2 & 15.4 & 2 & 15.4 & 13 & 0.45 \\
\hline Decreased RBS & 4 & 66.7 & 0 & 0 & 2 & 33.3 & 6 & 0.49 \\
\hline Abnormal RFT & 5 & 100 & 0 & 0 & 0 & 0 & 5 & 0.42 \\
\hline
\end{tabular}

Table 9. Profile of Other Laboratory Parameters

TSB-Total Serum Bilirubin. RBS-Random blood sugar, RFT Renal function of test

Out of 13 patients with increased TSB, majority (69.2\%) were PF positive. Out of 6 patients with decreased RBS, majority $(66.7 \%)$ were PF positive. Out of 5 patients with abnormal RFT, all were PF positive. But the association between them was found to be statistically not significant.

\begin{tabular}{|c|c|c|c|c|c|c|c|c|}
\hline \multirow[t]{2}{*}{ Symptoms } & \multicolumn{2}{|c|}{$\overline{P F}$} & \multicolumn{2}{|c|}{$\mathrm{PF}+\mathrm{PV}$} & \multicolumn{2}{|c|}{ PV } & \multirow[t]{2}{*}{ Total } & \multirow{2}{*}{$\begin{array}{l}P \\
\text { Value }\end{array}$} \\
\hline & $\mathbf{n}$ & 96 & n & 90 & $\mathrm{n}$ & 90 & & \\
\hline Fever & 86 & 75.4 & 8 & 7 & 20 & 17.5 & 114 & - \\
\hline Headache & 38 & 74.5 & 3 & 5.9 & 10 & 19.6 & 51 & 0.81 \\
\hline Myalga & 27 & 79.4 & 1 & 2.9 & 6 & 17.6 & 34 & 0.53 \\
\hline Vomiting & 43 & 79.6 & 6 & 11.1 & 5 & 9.3 & 54 & $0.03^{\circ}$ \\
\hline Loose stools & 19 & 69.2 & 1 & 3.8 & 6 & 23.1 & 26 & 0.57 \\
\hline $\begin{array}{l}\text { Abdominal } \\
\text { distension }\end{array}$ & 32 & 72.7 & 4 & 9.1 & 8 & 18.2 & 44 & 0.55 \\
\hline \begin{tabular}{|l} 
Jaundice \\
Jandice
\end{tabular} & 7 & 77.8 & 1 & 11.1 & 1 & 11.1 & 9 & 0.79 \\
\hline Bleeding & 8 & 100 & 0 & 0 & 0 & 0 & 8 & 0.24 \\
\hline Pallor & 18 & 85.7 & 1 & 4.8 & 2 & 9.5 & 21 & 0.47 \\
\hline $\begin{array}{l}\text { Altered } \\
\text { Sensorium }\end{array}$ & 20 & 83.3 & 2 & 8.3 & 2 & 8.3 & 24 & 0.40 \\
\hline Convulsions & 7 & 100 & 0 & 0 & 0 & 0 & 7 & 0.29 \\
\hline Dark urine & 5 & 100 & 0 & 0 & 0 & 0 & 5 & 0.42 \\
\hline $\begin{array}{l}\text { Shortmess of } \\
\text { Breath }\end{array}$ & 2 & 100 & 0 & 0 & 0 & 0 & 2 & 0.71 \\
\hline
\end{tabular}

\section{Table 10. Symptoms in Various Species of Plasmodium}

Patients with bleeding, convulsions, dark urine, shortness of breath are $100 \%$ positive for PF. Patients with Pallor and altered sensorium are around $80-90 \%$ positive for $\mathrm{PF}$. Patients with fever, headache, myalgia, vomiting, loose stools, abdominal distension, jaundice are around $70-80 \%$ positive for PF.

\begin{tabular}{|c|c|c|c|c|c|c|c|c|}
\hline \multirow[t]{2}{*}{ Signs } & \multicolumn{2}{|c|}{ PF } & \multicolumn{2}{|c|}{$\overline{P F+P V}$} & \multicolumn{2}{|c|}{ PV } & \multirow[t]{2}{*}{ Total } & \multirow{2}{*}{$\begin{array}{l}\mathbf{P} \\
\text { Value }\end{array}$} \\
\hline & $\mathbf{n}$ & $\%$ & n & $\%$ & $\mathbf{n}$ & $\%$ & & \\
\hline Pallor & 41 & 78.8 & 2 & 3.8 & 9 & 17.3 & 52 & 0.49 \\
\hline Icterus & 9 & 75 & 1 & 8.3 & 2 & 16.7 & 12 & 0.91 \\
\hline $\begin{array}{l}\text { Hepato- } \\
\text { splenomegaly }\end{array}$ & 10 & 83.3 & 1 & 8.3 & 1 & 8.3 & 12 & 0.56 \\
\hline Splenomegaly & 68 & 80 & 5 & 5.9 & 12 & 14.1 & 85 & $0.05^{*}$ \\
\hline
\end{tabular}


Hepato-splenomegaly is present in $83.3 \%$ PF positive cases, splenomegaly is present in $80 \% \mathrm{PF}$ positive cases, pallor is present in $78.8 \% \mathrm{PF}$ positive cases and icterus in $75 \%$ PF positive cases. Splenomegaly in falciparum and vivax species shows statistical significance.

\begin{tabular}{|c|c|c|c|c|c|c|c|c|}
\hline \multirow[t]{2}{*}{ Complications } & \multicolumn{2}{|c|}{ PF } & \multicolumn{2}{|c|}{$\mathbf{P F}+\mathbf{P V}$} & \multicolumn{2}{|c|}{ PV } & \multirow[t]{2}{*}{ Total } & \multirow{2}{*}{$\begin{array}{l}P \\
\text { Value }\end{array}$} \\
\hline & $\mathbf{n}$ & $\%$ & $\mathbf{n}$ & $\%$ & $\mathbf{n}$ & $\%$ & & \\
\hline Anemia & 32 & 80 & 3 & 7.5 & 5 & 12.5 & 40 & 0.58 \\
\hline Hypoglycemia & 3 & 75 & 1 & 25 & 0 & 0 & 4 & 0.26 \\
\hline Cerebral Malaria & 6 & 100 & 0 & 0 & 0 & 0 & 6 & 0.35 \\
\hline Hepatitis & 9 & 69.2 & 1 & 7.7 & 3 & 23.1 & 13 & 0.84 \\
\hline Renal failure & 4 & 100 & 0 & 0 & 0 & 0 & 4 & 0.50 \\
\hline $\begin{array}{l}\text { Bleeding } \\
\text { diathesis }\end{array}$ & 6 & 100 & 0 & 0 & 0 & 0 & 6 & 0.35 \\
\hline $\begin{array}{l}\text { Metabolic } \\
\text { acidosis }\end{array}$ & 4 & 100 & 0 & 0 & 0 & 0 & 4 & 0.50 \\
\hline Pulmonary edema & 2 & 100 & 0 & 0 & 0 & 0 & 2 & 0.71 \\
\hline $\begin{array}{l}\text { Repeated } \\
\text { convulsions }\end{array}$ & 1 & 100 & 0 & 0 & 0 & 0 & 1 & 0.84 \\
\hline Shock & 1 & 100 & 0 & 0 & 0 & 0 & 1 & 0.84 \\
\hline
\end{tabular}

\section{Table 12. Complications in Various Species of Plasmodium}

Patients with complications of cerebral Malaria, renal failure, bleeding diathesis, metabolic acidosis, pulmonary oedema, repeated convulsions, shock are $100 \%$ positive for PF. Anaemia is present in $80 \%$ PF positive cases, hypoglycaemia in $75 \%$ PF positive cases and hepatitis in $69.2 \%$ PF positive cases.

\begin{tabular}{|c|c|c|c|c|c|c|}
\hline & \multicolumn{3}{|c|}{ Smear for MP } & \multirow{3}{*}{$\begin{array}{c}\text { Total } \\
32 \\
\end{array}$} \\
\hline & & & PF & $\mathrm{PF}+\mathrm{PV}$ & PV & \\
\hline \multirow{6}{*}{$\begin{array}{l}\text { Haemoglobin } \\
\text { category }\end{array}$} & \multirow[t]{2}{*}{$<5.0 \mathrm{~g} / \mathrm{dl}$} & $\mathrm{n}$ & 26 & 2 & 4 & \\
\hline & & $\%$ & $30.2 \%$ & $25.0 \%$ & $20.0 \%$ & $28.1 \%$ \\
\hline & \multirow[t]{2}{*}{$5.0-7.0 \mathrm{~g} / \mathrm{dl}$} & $\mathrm{n}$ & 13 & 2 & 1 & 16 \\
\hline & & $\%$ & $15.1 \%$ & $25.0 \%$ & $5.0 \%$ & $14.0 \%$ \\
\hline & \multirow{2}{*}{$\begin{array}{l}>7.0-10.0 \\
\mathrm{~g} / \mathrm{dl}\end{array}$} & $\mathrm{n}$ & 47 & 4 & 15 & 66 \\
\hline & & $\%$ & $54.7 \%$ & $50.0 \%$ & $75.0 \%$ & $57.9 \%$ \\
\hline \multirow{2}{*}{\multicolumn{2}{|c|}{ Total }} & $\mathrm{n}$ & 86 & 8 & 20 & 114 \\
\hline & & $\%$ & $100.0 \%$ & $100.0 \%$ & $100.0 \%$ & $100.0 \%$ \\
\hline
\end{tabular}

PF positive have $54.7 \%$, PF+PV positive have $50 \%$, PV positive have $75 \%$ of patients with haemoglobin of $>7.0-10$ $\mathrm{g} / \mathrm{dl}$. But the association between them is not statistically significant.

\begin{tabular}{||l|c|c|}
\hline \multicolumn{1}{|c|}{ Outcome } & Frequency & Percent \\
\hline Death & 2 & $1.8 \%$ \\
\hline Recovered & 111 & $97.4 \%$ \\
\hline Referral & 1 & $0.9 \%$ \\
\hline Total Table 14. Distribution of Outcome \\
\hline \multicolumn{2}{|c|}{} \\
\hline
\end{tabular}

97.4\% patients recovered from illness, death occurred in $1.8 \%$ patients.

\begin{tabular}{|c|c|c|c|c|c|c|}
\hline & & & \multicolumn{3}{|c|}{ Age category } & \multirow[t]{2}{*}{ Total } \\
\hline & & & $\begin{array}{c}<5 \\
\text { YEARS }\end{array}$ & $\begin{array}{c}5-10 \\
\text { YEARS }\end{array}$ & $\begin{array}{c}11-15 \\
\text { YEARS }\end{array}$ & \\
\hline \multirow[t]{6}{*}{ Outcome } & \multirow[t]{2}{*}{ Death } & $\mathrm{n}$ & 1 & 0 & 1 & 2 \\
\hline & & $\%$ & $1.7 \%$ & $0.0 \%$ & $6.7 \%$ & $1.8 \%$ \\
\hline & \multirow[t]{2}{*}{ Recovered } & $\mathrm{n}$ & 57 & 40 & 14 & 111 \\
\hline & & $\%$ & $98.3 \%$ & $97.6 \%$ & $93.3 \%$ & $97.4 \%$ \\
\hline & \multirow[t]{2}{*}{ Referral } & $\mathrm{n}$ & 0 & 1 & 0 & 1 \\
\hline & & $\%$ & $0.0 \%$ & $2.4 \%$ & $0.0 \%$ & $0.9 \%$ \\
\hline \multirow{2}{*}{\multicolumn{2}{|c|}{ Total }} & $\mathrm{n}$ & 58 & 41 & 15 & 114 \\
\hline & & $\%$ & $100.0 \%$ & $100.0 \%$ & $100.0 \%$ & $100.0 \%$ \\
\hline
\end{tabular}

\section{Table 15. Association Between Outcome and Age Category}

98.3\% patients recovered in $<5$ years age group, $97.6 \%$ patients recovered in 5-10 years age group and $93.3 \%$ patients recovered in 11-15 age group years. But the association between them was found to be statistically not significant.

\section{DISCUSSION}

1. Majority of the study subjects belong to age group of $<5$ years (50.9\%), followed by age group of 5-10 years (36\%) and 11-15 years (13.2\%). In a study by Tarakeswara Rao et al, 5 Majority of the study subjects belong to age group of $<5$ years (47.2\%), followed by age group of 5-10 years (29.6\%) and 11-15 years (19.4\%). In the study by Sathpathy et $a^{6} 62.8 \%$ cases of malaria were above 5 years.

2. Majority of the study subjects were boys (64\%) followed by girls (36\%).

\begin{tabular}{|c|c|c|c|c|c|}
\hline Gender & $\begin{array}{c}\text { Murthy } \\
\text { GL et al7 }\end{array}$ & $\begin{array}{c}\text { Talib } \\
\text { VH } \\
\text { et al8 }\end{array}$ & $\begin{array}{c}\text { Sathpathy } \\
\text { SK et al6 }\end{array}$ & $\begin{array}{c}\text { Tarakeswara } \\
\text { Rao et al }\end{array}$ & $\begin{array}{c}\text { Present } \\
\text { Study }\end{array}$ \\
\hline Boys & $69.6 \%$ & $66.7 \%$ & $62.5 \%$ & $67.6 \%$ & $64.0 \%$ \\
\hline Girls & $31.4 \%$ & $33.3 \%$ & $37.5 \%$ & $32.4 \%$ & $36.0 \%$ \\
\hline
\end{tabular}

Table 16. Comparison of Gender in Different Studies

3. All the study subjects presented with fever (100\%). Majority of the patients presented with vomiting (47.4\%) and headache (44.7\%). 38.6\% study subjects presented with abdominal distension, $29.8 \%$ presented with myalgia, $22.8 \%$ presented with loose stools, $21.1 \%$ presented with altered sensorium, $18.4 \%$ presented with pallor, Jaundice in $7.9 \%$, bleeding in $7.0 \%$, convulsions in $6.1 \%$, dark urine in $4.4 \%$ and shortness of breath in $1.8 \%$ of the study subjects. 


\begin{tabular}{|c|c|c|c|c|c|}
\hline Clinical Features & Mehta SR et al9 & Murthy GL et al7 & Talib VH et al8 & Tarakeswara Rao et al 5 & Present Study \\
\hline Fever & $94.6 \%$ & $98.10 \%$ & $97.76 \%$ & $100 \%$ & $100 \%$ \\
\hline Headache & $33.45 \%$ & $33.4 \%$ & $73.81 \%$ & - & $44.7 \%$ \\
\hline Myalgia & - & - & $67.59 \%$ & - & $29.8 \%$ \\
\hline Vomiting & $8.47 \%$ & - & $54.75 \%$ & - & $47.4 \%$ \\
\hline Diarrhoea & - & $5.64 \%$ & - & - & $22.8 \%$ \\
\hline Breathlessness & $1.17 \%$ & $0.63 \% \%$ & - & $13.9 \%$ & $1.8 \%$ \\
\hline Convulsion & - & $2.53 \%$ & - & $18.5 \%$ & $6.1 \%$ \\
\hline Bleeding & $0.7 \%$ & $4.43 \%$ & $0.16 \%$ & - & $7 \%$ \\
\hline Pallor & - & - & - & $43.5 \%$ & $45.6 \%$ \\
\hline Icterus & $2.58 \%$ & $23.41 \%$ & - & $10.2 \%$ & $10.5 \%$ \\
\hline Splenomegaly & - & - & $29.60 \%$ & $28.7 \%$ & $74.6 \%$ \\
\hline Hepatosplenomegaly & - & - & $24.58 \%$ & $25.9 \%$ & $10.5 \%$ \\
\hline
\end{tabular}

\section{Symptoms}

\section{Fever}

$100 \%$ of patients had complained of fever. A study by Murthy GL et al ${ }^{7}$ showed that fever 77 with chills and rigors in

$98.10 \%$ of patients which is comparable. Another study by Talib VH et al ${ }^{8}$ showed it to be $97.76 \%$.

\section{Headache}

Headache was present in $44.7 \%$ of patients. It was present in $33.4 \%$ in study by Murthy GL et al ${ }^{7}$ and $33.45 \%$ in study by Mehta SR et al. ${ }^{9}$

\section{Myalgia}

In our study it was seen in $29.8 \%$ of patients. The study by Talib VH et al ${ }^{8}$ showed it was in $67.59 \%$.

\section{Vomiting}

In our study it was present in $47.4 \%$ of patients. In study by S.R. Mehta SR et al $^{9}$ it was $8.47 \%$ and study by Talib VH et al ${ }^{8}$ it was $57.75 \%$.

\section{Jaundice}

Yellowish discoloration of eyes was complained by $10.5 \%$ of our patients. It was $23.41 \%$ in study by Murthy GL et al 7 . High incidence of jaundice was because of the haemolysis caused by malaria parasite.

\section{Diarrhoea}

$22.8 \%$ of our patient had diarrhoea. In the study by Murthy GL et al7it was $5.64 \%$

\section{Bleeding}

The incidence was $7 \%$ in our study. It was $4.43 \%$ in the study by Murthy GL et al. ${ }^{7}$
Splenomegaly was present in $63 \%$ cases in our study.

This finding is consistent with study by Milind BK et al 10 where splenomegaly was present in $53 \%$ of cases. Hepatomegaly was seen in $52 \%$ cases in our study. In a study by Milind BK et al ${ }^{10}$ hepatomegaly was seen in $47 \%$ of cases.

5. In smear for $\mathrm{MP}, \mathrm{PF}$ is positive in $75.4 \%, \mathrm{PF}+\mathrm{PV}$ in $7 \%$ and $\mathrm{PV}$ in $17.5 \%$ cases. In RDT, PF is positive in $71.9 \%$, $\mathrm{PF}+\mathrm{PV}$ in $11.4 \%$ and $\mathrm{PV}$ in $16.7 \%$ cases.? In a study by Verma $\mathrm{P}$ et al, ${ }^{11}$ Maximum number of patients were of $\mathrm{Pf}$ (57.8\%); Pv was documented in $13.7 \%$ and mixed infection in $27.4 \%$ cases.

6. Patients with bleeding, convulsions, dark urine, shortness of breath were $100 \%$ positive for PF. Patients with Pallor and altered sensorium were around $80-90 \%$ positive for PF. Patients with fever, headache, myalgia, vomiting, loose stools, abdominal distension, jaundice were around $70-80 \%$ positive for PF.

7. Hepato-splenomegaly is present in $83.3 \% \mathrm{PF}$ positive cases, splenomegaly is present in $80 \%$ PF positive cases, Pallor is present in $78.8 \% \mathrm{PF}$ positive cases and icterus is present in $75 \% \mathrm{PF}$ positive cases. Splenomegaly shows statistical significance.

8. Patients with complications of cerebral Malaria, renal failure, bleeding diathesis, metabolic acidosis, pulmonary oedema, repeated convulsions, shock were 100\% positive for PF. Anaemia is present in $80 \%$ PF positive cases, hypoglycaemia is present in $75 \% \mathrm{PF}$ positive cases and hepatitis is present in $69.2 \% \mathrm{PF}$ positive cases.

\begin{tabular}{|c|c|c|c|c|c|c|c|}
\hline Complication & $\begin{array}{c}\text { Murthy GL } \\
\text { et al }\end{array}$ & $\begin{array}{c}\text { Kochar } \\
\text { DK et al } \mathbf{1 2}^{\mathbf{2}}\end{array}$ & $\begin{array}{c}\text { Mohapatra } \\
\text { MK }^{\mathbf{1 3}}\end{array}$ & $\begin{array}{c}\text { Satpathy } \\
\text { et al6 }\end{array}$ & $\begin{array}{c}\text { Al-Taiar A } \\
\text { et al14 }\end{array}$ & $\begin{array}{c}\text { Mockenhau } \\
\text { Pt15 }\end{array}$ & $\begin{array}{c}\text { Present } \\
\text { study }\end{array}$ \\
\hline Anaemia & $74.68 \%$ & $26.04 \%$ & $6.9 \%$ & $26 \%$ & $37 \%$ & $55 \%$ & $35.08 \%$ \\
\hline Cerebral Malaria & $48.1 \%$ & $10.94 \%$ & $74.3 \%$ & $40 \%$ & $8 \%$ & $17 \%$ & $5.26 \%$ \\
\hline Acute Renal Failure & $24.68 \%$ & $6.25 \%$ & - & $14 \%$ & $9 \%$ & - & $3.50 \%$ \\
\hline Hypoglycaemia & $8.22 \%$ & $1.56 \%$ & - & $13 \%$ & $8 \%$ & $17 \%$ & $3.50 \%$ \\
\hline Hypotension/Shock- & - & $10.94 \%$ & - & - & - & - & $0.87 \%$ \\
\hline Bleeding Diathesis & $16.45 \%$ & $25.52 \%$ & - & $3.7 \%$ & $3 \%$ & - & $5.36 \%$ \\
\hline Pulmonary Oedema & $11.39 \%$ & $2.08 \%$ & - & $2 \%$ & - & - & $1.75 \%$ \\
\hline \multicolumn{7}{|c|}{ Table 18. Comparison of Complications in Different Studies } \\
\hline
\end{tabular}


9. In our study, the most common complication was anaemia (35.08\%) followed by hepatitis (11.40\%), Bleeding diathesis (5.36\%), cerebral malaria (5.26\%), hypoglycaemia (3.50\%), renal failure (3.50\%), metabolic acidosis $(3.50 \%)$, pulmonary oedema $(1.75 \%)$, repeated convulsions $(0.87 \%)$ and shock $(0.87 \%)$.

- In a study by Murthy GL et al,7 anaemia (74.6\%) and cerebral malaria $(48.1 \%)$ were the common manifestations.

- In a study by Kochar et al,12 anaemia were most common manifestations followed by DIC and cerebral malaria. This shows that the spectrum of common manifestations and complications of malaria vary in different geographical regions depending upon parasitic factor, epidemiological factors and host defence factors.

10. $\mathrm{PF}$ positive cases (54.7\%), $\mathrm{PF}+\mathrm{PV}$ positive cases $(50 \%)$, $\mathrm{PV}$ positive cases $(75 \%)$ are more in patients with haemoglobin of $>7.0-10 \mathrm{~g} / \mathrm{dl}$. But the association between them was found to be statistically not significant.

\begin{tabular}{|c|c|c|}
\hline Haemoglobin (gm \%) & Murthy GL et al7 & Present Study \\
\hline Mild (>7-10) & $43.67 \%$ & $57.9 \%$ \\
\hline Moderate (5-7) & $21.51 \%$ & $14 \%$ \\
\hline Severe (<5) & $9.49 \%$ & $28.1 \%$ \\
\hline Table 19. Comparison of Haemoglobin in Different Studies \\
\hline
\end{tabular}

11. $97.4 \%$ patients recovered from illness, death occurred in $1.8 \%$ patients. The Overall mortality was $1.8 \%$ in our study. Out of 2 deaths, one due to falciparum and another due to vivax. $98.3 \%$ patients recovered in $<5$ years age group, 97.6\% patients recovered in 5-10 years age group and 93.3\% patients recovered in 11-15 age group years. But the association between them was found to be statistically not significant.

\begin{tabular}{|c|c|c|c|c|c|c|}
\hline & 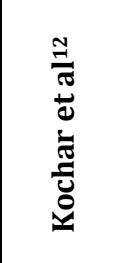 & 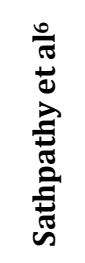 & 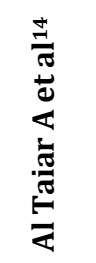 & 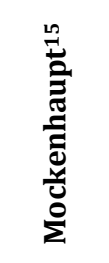 & 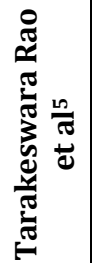 & 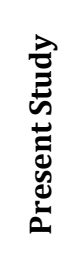 \\
\hline Mortality \% & $10.93 \%$ & $9.9 \%$ & $3.2 \%$ & $11.2 \%$ & $5.5 \%$ & $1.8 \%$ \\
\hline \multicolumn{7}{|c|}{$\begin{array}{l}\text { Table 20. Comparison of Mortality Rate in Different } \\
\text { Studies }\end{array}$} \\
\hline
\end{tabular}

\section{CONCLUSION}

Majority of the subjects in this study were $<5$ years of age and most were males. All the study subjects presented with fever. Majority of the patients also had vomiting and headache. A third of patients had abdominal distension and myalgias. Less prevalent symptoms were bleeding, convulsions, dark urine and shortness of breath. On examination, majority of the subjects had splenomegaly and pallor. Complications like anaemia, hypoglycaemia, renal failure, cerebral malaria, metabolic acidosis, shock were more prevalent in $<5$ years age group. Majority were infected with falciparum malaria and also had more complications. Cerebral malaria, renal failure, bleeding diathesis, metabolic acidosis, pulmonary oedema, repeated convulsions, shock were noted only in falciparum malaria. Mortality was $1.8 \%$ in this study. Majority of patients recovered.

\section{REFERENCES}

[1] World Health Organisation. World Malaria report. Geneva: 2015. http://apps.who.int/iris/bitstream/10665/200018/1 /9789241565158_eng.pdf.

[2] Kumari M, Ghildiyal R. Clinical profile of plasmodium vivax malaria in children and study of severity parameters in relation to mortality: a tertiary care centre perspective in Mumbai, India. Article ID 765657, Hindawi Publishing Corporation, Malaria Research and Treatment 2014;2014:1-6.

[3] Strategic plan for malaria control in India. 2012-2017: A five-year strategic plan. Directorate of National Vector Borne Disease Control Programme. Directorate General of Health Services. Ministry of Health \& Family Welfare, Government of India. http://nvbdcp.gov.in/Doc/Strategic-Action-Plan-M alaria-2012-17-Co.pdf. Accessed May 23, 2018.

[4] Schumacher RF, Spinelli E. Malaria in Children. Mediterr J Hematol Infect Dis 2012;4:1-12.

[5] TarakeswaraRao P, Prudhvi K. Clinical Profile of admitted children with malarial fever: a retrospective study. Int J Pediatr Res 2016;3(9):678-82.

[6] Satpathy SK, Mohanty N, Nanda P, et al. Severe falciparum malaria. Indian J Pediatr 2004;71(2):133-5.

[7] Murthy GL, Sahay RK, Srinivasan VR, et al. Clinical profile of falciparum malaria in a tertiary care hospital. J Ind Med Assoc 2000;98(4):160-2, 169.

[8] Talib VH, Hasija BD, Diwan VM, et al. A clinico haematological profile of malaria. J Assoc Physicians India 1982;30(6):402-4.

[9] Mehta SR, Naidu G, Chandar V, et al. Falciparum malaria-present day problems - an experience with 425 cases. J Assoc Physicians India 1989;37(4):264-7.

[10] Milind BK, Pradeep PR, Hussain ZF. Cerebral malaria in rural India. Indian J Pediatr 2002;69(8):659-61.

[11] Verma P, Shukla US, Kalraiya A. Retrospective study on clinical profile of severe malaria in children admitted in a tertiary care centre of Central India. People's Journal of Scientific Research 2014;7(1):22-6.

[12] Kochar DK, Kochar SK, Agarwal RP. The changing spectrum of severe falciparum malaria: a clinical study from Bikaner (northwest India). J Vector Borne Dis 2006;31(9):2278-84.

[13] Mohapatra MK. The Natural history of complicated falciparum malaria - a prospective study. J Assoc Physicians India 2006;54:848-53.

[14] Al-Taiar A, Jaffar S, Assabri A, et al. Severe malaria in children in Yemen: two site observational study. Brit Med J 2006;333(7573):827-32.

[15] Mockenhaupt FP, Ehrhardt S, Burkhardt J, et al. Manifestation and outcome of severe malaria in children in northern Ghana. Am J Trop Med Hyg 2004;71(2):167-72. 